\title{
Spirituální citlivost charitních služeb: Proč a jak pracovat se spirituální dimenzí životní situace klientư ${ }^{1}$ Jakub Doležel
}

Otevírat téma spirituální dimenze, resp. spirituálních potřeb adresátů charitních služeb, tedy primárně služeb poskytovaných v institučních zařízeních charit, ${ }^{2}$ by mohlo být z pozice vzdáleného pozorovatele považováno za nadbytečné $z$ důvodu naprosté samozřejmosti. Služba potřebným v duchu lásky (diakonia) je v katolické církvi pokládána spolu s liturgií a kérygmatem za integrální součást jejího poslání a niterný výraz její podstaty. ${ }^{3}$ Kodex Charity ČR uvádí duchovní pomoc jako cestu k naplňování svého poslání. ${ }^{4}$ Množství signálů však naznačuje, že realita charitních služeb je tomuto ideálu mnohdy značně vzdálená.

Cílem tohoto článku je představit procesuální model, který umožní personálu charitních zařízení doplnit bio-psycho-sociální koncept jejich práce s př́ijemci služby také o spirituální komponentu, pokud v něm chybí. Kvalifikační zařazení personálu (lékař, ošetřovatel, sociální pracovník, terapeut, pracovník v sociálních službách atd.) zde není striktně rozlišováno, i když model nezapírá inklinaci k sektoru sociální práce, odkud také vydatně čerpá, nechybí ale ani přesahy do zdravotnictví.

V jakém smyslu je řeč o modelu? V dosavadní české odborné literatuře není tématika spirituality, resp. spirituálních potřeb adresátů sociálních či zdravotních služeb neznámá. Ošetřovatelství, ${ }^{5}$

1 Publikace vznikla za podpory projektu Profesionalizace a deprofesionalizace $\mathrm{v}$ praxi české sociální práce, reg. číslo IGA_ CMTF_2017_010.

2 Při platnosti stejného teologického východiska, které je uvedeno níže v textu, by se text dal vztáhnout i na zařízení evangelických diakonií. Za předpokladu adekvátního proškolení by to bylo možno i v kontextu služeb zajištovaných dobrovolnicky.

3 Srov. Deus caritas est 25 a.

4 @ Charita ČR, Kodex Charity Česká Republika, bod 1.4 (online), dostupné na:http://www.charita.cz/res/data/000077.pdf?seek=1294994736, citováno dne 1.2.2017.

5 Srov. Erika HAJNOVÁ FUKASOVÁ - Radka BUŽGOVÁ - David FELTL, Hodnocení duchovních potřeb pacientů v paliativní péči, Klinická onkologie 1/2015, s. 13-19; Erika HAJNOVÁ - Radka BUŽGOVÁ, Hodnocení spirituálních potřeb u pacientů s onkologickým onemocněním: Pilotní studie, Ošetřovatelství a porodní asistence 4/2013, s. 708-714; Igor ONDREJKA - Katarína ŽIAKOVÁ - Ivan FARSKÝ, Diagnostika spirituálnych potrieb u pacientov, in: Ošetřovatelská diagnostika a praxe založená na dủkazech II, eds. Radka BUŽGOVÁ - Lucie SIKOROVÁ, Ostrava: Ostravská univerzita v Ostravě, Zdravotně sociální fakulta, 2008, s. 15-20; Jitka NĚMCOVÁ, Saturace spirituálních potřeb pacientů, Diagnóza v ošetřovatelství 1/2010, s. 26-29; Margaret O'CONNOR - Sanchia ARANDA (eds.), Paliativní péče. Pro sestry všech oborů, Praha: Grada, 2005; Radka BUŽGOVÁ - Renáta ZELENÍKOVÁ, Vytvoření měřícího nástroje pro hodnocení potřeb pacientů v paliativní péči v souvislosti s kvalitou života: Hodnocení potřeb pacientů v paliativní péči (PNAP), Ošetrovatelství a porodní asistence 2/2012, s. 404-414; Marie SVATOŠOVÁ, Víme si rady s duchovními potřebami nemocných?, Praha: Grada, 2012. 
sociální práce ${ }^{6}$ i pastorální teologie ${ }^{7}$ již disponují větším či menším souborem publikací. Vždy jde ale o uchopení dílč́ho momentu, např́ílad obsahu duchovních potřeb, měření naplněnosti duchovních potřeb, nebo typologie intervencí. V nabídce však absentuje určitý model, který pomůže personálu charitních zařízení zakomponovat tématiku spirituality do linie vzájemně návazných praktických kroků při přípravě na praxi a samotným započetím s praxí. Vzájemná provázanost částí modelu a úsilí autora o poskytnutí podnětů $\mathrm{k}$ prímé praxi zdůvodňuje na jedné straně rozsah článku, na druhou stranu si materiál článku rozhodně nenárokuje ucelenost tématiky.

\section{Proč?}

\section{Reduktivní charitní praxe?}

Na úrovni zprostředkované zkušenosti se mohu opírat o opakované zprávy studentů našich oborů, kteří se během své odborné praxe v charitních zařízeních častěji nesetkávají, než setkávají se systematickým konceptem např. práce s duchovními potřebami uživatelů. Tato zkušenost se mi fragmentárně potvrdila i $v$ rámci výzkumného šetření mého diplomanta mezi osmi klienty terénní služby jedné moravské charity, kteří po absolvování tzv. spirituálního posouzení vyjádřili určité zklamání: „chtěla bych, aby mi pracovníci pomohli i v této (duchovní) oblasti“, nebo „jsem rád, že si o tom duchovnu můžu promluvit, protože tady ve středisku není o tom s kým mluvit“.

Na úrovni osobní zkušenosti mohu poukázat na šiři zájmu, se kterým se nabídka dalšího vzdělávání v této tématice setkává u pracovníků charitních služeb, kteří po jakékoliv praktické metodické podpoře takříkajíc hladoví. Bohužel, dosud nemáme $\mathrm{k}$ dispozici empirické údaje, které by umožňovaly testovat zobecnění těchto dílčích signálů $\mathrm{z}$ charitních zařízení. Je však možné poukázat na další signály ze společného prostředí sociálních služeb, které ukazují stejným směrem. $\mathrm{Na}$ absenci integrace spirituální roviny životní situace př́ijemců sociální služeb dovoluje usuzovat absolventská práce další mé diplomantky, která testovala použitelnost spirituálního posouzení u souboru osmi seniorů v klasickém pobytovém zařízení. Akceptaci tohoto způsobu práce s klienty hodnotila takto: „V̌̌ichni zúčastnění se vyjádřili více než kladně k použití duchovního posouzení s tím, že by se jim líbilo, kdyby se na jejich víru a potřeby v této oblasti ptal někdo častěji."

Ještě výmluvněji působí výsledky kvalitativního výzkum, který u dvaceti klientů dvou pobytových zařízení pro seniory v jižních Čechách realizovala Věra Suchomelová. ${ }^{10}$ Poznatky jejího výzkumu odkryly stav, který nelze označit jinak než jako ,past', jejiž obětí jsou jak sociální/zdravotnický personál, tak pastorační pracovníci, pokud se vůbec na poskytované službě podílí, a samozřejmě na konci i samotní senioři. Personál totiž mylně redukuje péči o duchovní potřeby na liturgické

6 Srov. Eva KŘİŽZVÁ, Specific Techniques of Exploring Spirituality as Part of Holistic Social Work, Czech and Slowak Social Work: ERIS Journal 4/2016, s. 50-56; Jan KAŇÁK, Postavení diskursu spirituality v sociální práci, Sociální práce / Sociálna práca 4/2015, s. 30-46; Jan KAŇÁK, Nedefinovaná profesionalita: Vztah diskursů spirituality a profesionality v sociální práci v soudobé odborné literatuře, Sociální práce / Sociálna práca 5/2016, s. 72-91; Věra SUCHOMELOVÁ, Spirituální potřeby seniorů v sociální péči, Sociální práce / Sociálna práca 5/2016, s. 92-108.

7 Srov. Věra SUCHOMELOVÁ, Pastorace v domově pro seniory: vybrané otázky, Caritas et veritas 5/2015, s. 112-121; Věra SUCHOMELOVÁ, Senioři a spiritualita. Duchovní potřeby v každodenním životě, Praha: Návrat domů, 2016.

8 (C) Tomasz GIERCZUSZKIEWICZ, Použití konceptu duchovního posouzení podle Davida R. Hodge v kontextu sociální práce s osobami bez domova (online), bakalářská práce, Olomouc: Univerzita Palackého v Olomouci, Cyrilometodějská teologická fakulta, 2013, s. 58, dostupné na: http://theses.cz/id/9fi033/, citováno dne 1. 2. 2017.

9 (C) Marie SCHREIEROVÁ, Koncept duchovního posouzení podle Davida R. Hodge v českém prostředí při práci s klienty Domova pro seniory v Bruntále (online), absolventská práce, Olomouc: CARITAS - Vyšší odborná škola sociální Olomouc, 2015, s. 40, dostupné na: http://theses.cz/id/4i9iho/, citováno dne 1. 2. 2017.

10 Viz pozn. 6 výše. 
situace a kontakt se specializovaným profesionálem - duchovním/pastoračním asistentem. Klienti však takové specializované profesionály nepovažují za partnery pro duchovní rozhovor, jehož obsahem by byly životní těžkosti a existenciální témata jejich životní situace, jelikož veškerá pastorační agenda obsahovala pouze mši, podávání eucharistie a modlitbu růžence. ${ }^{11}$

\section{Teoretické předpoklady}

Jan Kaňák ve své stati o diskurzech profesionality a spirituality v sociální práci navrhl rozlišit pět typů jejich souvztažnosti, ${ }^{12}$ přičemž doporučuje, aby autoři publikující na tomto poli vždy vyjasnili: ${ }^{13}$

- co pro ně znamená profesionální a spirituální diskurz;

- ze kterého diskurzu do svého tématu vstupují;

- který z typů souvztažnosti chtějí rozvíjet.

Z hlediska diskurzu profesionality lze těmto požadavkům vyhovět jen analogicky, jelikož diskurz profesionality charitních služeb není totožný s diskurzem profesionality sociální práce, nebot se vlastně nejedná o samostatnou profesi, nýbrž specifickou a širokospektrální oblast pomáhající praxe a pomáhajících profesí. Pokud v rámci tohoto profesního spektra zvolím jako referenční bod sociální práci, pak se argumentace této studie nejvíce kryje s modelem spirituálně senzitivní sociální práce, která usiluje i o reflexivní zvládání života a sociální fungování klientů. ${ }^{14}$ Leitmotivem tohoto typu diskurzu spirituality v sociální práci je potřeba rozpoznat klientův systém orientace v životě, tedy to, co považuje za významné pro své fungování a zvládání klient a nikoliv primárně pracovník či organizace, a následně toto poznané zmobilizovat a integrovat do intervence. O způsobu ukotvení diskurzu spirituality v prostředí ošetřovatelství bude krátce řeč později.

Není pochyb o tom, že se $\mathrm{v}$ charitních zařízeních nemůžeme zříci odpovědnosti za nabídku křestanské, ba dokonce katolické kultivace spirituálních dispozic klientů, a pomocí například sakramentálních nástrojů otevírat prostor pro působení Božího Ducha v srdci člověka. Nebot’ teprve tam, kde v člověku může působit Duch svatý, dosahují přirozené spirituální dispozice svého posledního cíle. Toto nadpřirozené působení Ducha Božího na ducha lidského má ovšem své přirozené předpoklady, které je třeba respektovat a také kultivovat ve smyslu scholastické zásady gratia supponit naturam, tedy milost předpokládá přirozenost. V následujícím textu chci věnovat pozornost právě této antropologické „první vrstvě“ a dále nastínit soubor několika nástrojů, jejichž osvojení u některých charitních pracovníků by mohlo přinést novou úroveň jejich služby člověku. ${ }^{15} \mathrm{~V}$ tomto nastavení je předkládaný model kompatibilní s celostním konceptem charitní praxe.

11 Věra SUCHOMELOVÁ, Pastorace v domově pro seniory, s. 113.

12 Spirituálně senzitivní sociální pracovník; duchovní pracovník inspirovaný sociální prací; spirituálně senzitivní sociální práce; spirituálně orientovaná sociální práce; teologie senzitivní k sociální práci. Srov. Jan KAŇÁK, Nedefinovaná profesionalita, s. 72-91.

13 Srov. tamtéž, s. 87.

14 Srov. tamtéž, s. 82-84.

15 Tuto poučku můžeme použít v tom smyslu, že spásné jednání Boha vưči člověku (milost) nevylučuje a neruší Bohem ustanovené přirozené zákonitosti lidské přirozenosti, jak je poznáváme ve světle poznatků psychologie, sociologie, biologie atd. Milost fungujícího, zdařilého vztahu člověka k sobě samému, $\mathrm{k}$ druhým, ke stvořenému světu a $\mathrm{k}$ Bohu chce tedy stavět na přirozených základech vložených do člověka a tyto neobcházet a nepotlačovat. V tomto smyslu má životodárný náboženský vztah člověka k Bohu Otci, skrze Ježíše Krista v Duchu svatém, jak to formulují křestané, své přirozené spirituální předpoklady, k jejichž porozumění chce tento článek přispět. Srov. Heinrich POMPEY, Beziehungstheologie: Das Zueinander theologischer und psychologischer „Wirk“-lichkeiten und die biblisch/ theologische Kontextualisierung von Lebens- und Leidenserfahrungen, in: Caritas - Das menschliche Gesicht des Glaubens: Ökumenische und internationale Anstöße einer Diakonietheologie, ed. Heinrich POMPEY, Würzburg: Echter, 1997, s. 92-106. 


\section{Celostní koncept charitní praxe}

$\mathrm{V}$ prostředí teoretické konceptualizace charitní praxe, jak ji v celosvětově ojedinělém měřítku rozvijí „Caritaswissenschaft", ve veřejných deklaracích vlastního profilu jednotlivých charitních zařízení, které může vnější pozorovatel snadno nalézt na webových stránkách pod záložkou „Kdo jsme?" nebo „Co nabízíme?“, či v základním dokumentu (Leitbild, Kodex), je pokládáno za standard, že charitní praxe chce a měla by reagovat na lidské potřeby ve všech jejich úrovních, včetně oněch duchovních/spirituálních.

Pompey a Roß tento postulát formulují implicitně, když svazují charitní praxi s „vícedimenzním pojetím člověka“, ${ }^{16}$ což podle nich vede ke kritickému postoji vůči různým „reduktivním perspektivám a modelům ${ }^{\text {“ }}{ }^{17}$ Haslinger konkretizuje svůj požadavek integrálního pojetí člověka v charitní praxi jako odpověd' na celek jeho potřeb: tělesných, psychických, sociálních a duchovních. ${ }^{18}$ Ani jeden $\mathrm{z}$ autorů však neposkytuje praktické podněty, návrhy či instrukce, jak tento požadavek naplnit.

Postulát celostního pojetí charitní praxe rovněž bezproblémově koreluje s teorií uplatňovanou v prostředí katolické sociální etiky, resp. katolické sociální nauky. Zde se teorie potřeb uvádí v souvislosti s konceptem integrálního rozvoje člověka, jak jej načrtnula encyklika Populorum progressio a aktualizovala encyklika Caritas in veritate. Podle posledně jmenovaného dokumentu se integrální rozvoj člověka „týká celé lidské osoby ve všech jejích dimenzích“. ${ }^{19}$ Paradigma integrálního rozvoje člověka a nikoli jen celostní př́stup $\mathrm{k}$ jeho potřebám podle mého názoru silně konvenuje s dalším typem souvztažností diskurzů, jak je rozlišil Kaňák: spirituálně orientovaná sociální práce otevírající prostor „spirituální transformaci klientů a klientek“.20 Argumentaci a nástroje rozvíjené v tomto př́spěvku lze tedy částečně chápat i ve světle tohoto typu vztahu diskurzu profesionality a spirituality.

\section{Poznatky o pozitivních efektech spirituality a religiozity na zdraví a sociální fungování}

Ve způsobu odpovědi na otázku, proč integrovat do charitních služeb i sféru spirituality jejich prŕijemců, nelze pominout změnu klimatu, ke které došlo s ohledem na koncepty spirituality a religiozity v posledních dekádách ve zdravotnictví a sociální práci.

V oblasti medicínského a ošetrovatelského výzkumu se v 80. a zejména 90. letech minulého století probudil masivní zájem o spiritualitu/religiozitu a jejich vliv na zdraví. Dokonce i Světová zdravotnická organizace (dále jen WHO) navzdory aktuální definici zdraví, uvádějící jen jeho fyzické, psychické a sociální komponenty, ${ }^{21}$ zařadila doménu spirituality do oficiálního nástroje posouzení kvality života WHOQOL. ${ }^{22} \mathrm{~V}$ roce 1995 WHO také uznala poskytování spirituální opory za pod-

16 Heinrich POMPEY - Paul-Stefan ROSS, Kirche für andere. Handbuch für eine diakonische Praxis. Mainz: Grünewald Verlag, 1998, s. 207.

17 Tamtéž, s. 186.

18 Srov. Herbert HASLINGER, Diakonie: Grundlagen für die soziale Arbeit der Kirche, Paderborn-München-Wien-Zürich: Ferdinand Schöningh, 2009, s. 314.

19 Caritas in veritate 11. Dalším příbuzným konceptem je integrální humanismus, jak o něm úvodem hovoří Kompendium sociální nauky církve (čl. 19).

20 Jan KAŇÁK, Nedefinovaná spiritualita, s. 84.

21 Srov. @ Světová zdravotnická organizace, Konstituce Světové zdravotnické organizace, (online), dostupné na: http://www.who.int/ governance/eb/who_constitution_en.pdf, citováno dne 1.2. 2017.

22 Srov. Margaret HOLLOWAY, Spiritual Need and the Core Business of Social Work, British Journal of Social Work 2/2007, s. 266. 
statnou součást paliativní péče. ${ }^{23} \mathrm{Na}$ půdě WHO se rovněž vede diskuze o tzv. 4. dimenzi zdraví a již byly vytvořeny nástroje $\mathrm{k}$ jejímu měření. ${ }^{24}$

Nejlepší ilustrací lékařského zájmu o roli spirituality/religiozity je Př́ručka náboženství a zdraví (Handbook of Religion and Health) od amerického profesora psychiatrie Haralda G. Koeniga a kolegů. Ve svém prvním vydání zde Koenig a jeho kolegové sumarizovali výsledky více než 1000 výzkumných studií, které prokázaly větší či menší korelaci s různými oblastmi tělesného i duševního zdraví. ${ }^{25}$ Ve druhém vydání roku 2012 tato př́ručka (na více než 1200 stranách) identifikovala již přes 3000 studií. ${ }^{26}$ Religiozita a spiritualita tedy koreluje pozitivně se: ${ }^{27}$

- zvýšenou adaptací na ztrátu blízké osoby;

- sociální oporou;

- Životní spokojeností;

- pocitem štěstí, naděje a optimismu;

- vnímání smyslu a účelu života;

- sníženým pocitem úzkosti;

- sníženým pocitem opuštěnosti;

- sníženou mírou sebevražednosti;

- sníženou délkou psychiatrické hospitalizace;

- zvýšenou pravděpodobností remise schizofrenie;

- kvalitou života;

- zdravým životním stylem;

- vymaněním se z drogové závislosti;

- nižší mírou kouření;

- vyšší pocitovanou kontrolou nad vlastním tělesným a psychickým stavem;

- nižší mírou depresivity;

- vyšší mírou sebevědomí;

- nižším krevním tlakem;

- nižší úmrtností po srdeční operaci;

- vyšší průměrnou délkou života;

- vyšší schopností zvládat stres.

S podobnou situací jsme konfrontováni v oblasti sociální práce. Až do 80. let 20. století byla spiritualita a náboženství zanedbávaným tématem, což někteří autoři připisují „hluboce zakořeněné, historické antipatii vůči náboženství v sociální práci na Západě“ ${ }^{28}$ Teprve poté nastává v literatuře doslova renesance zájmu. První vydání reprezentativní práce Spiritualita a sociální práce: podrobná bibliografie s anotacemi (Spirituality and Social Work: A Comprehensive Bibliography

23 Srov. Aline NIXON - Aru NARAYANASAMY, The spiritual needs of neuro-oncology patients from patients' perspective. Journal of Clinical Nursing 15-16/2010, s. 2260.

24 Srov. Neera DHAR et al., Spiritual Health Scale 2011: Defining and Measuring 4th Dimension of Health, Indian Journal of Community Medicine 4/2011, s. 275-282.

25 Srov. Harald G. KOENIG - Michael E. MCCULLOGH - David B. LARSON, Handbook of Religion and Health, New York: Oxford University Press, 2001.

26 Srov. Harald G. KOENIG - Dana E. KING - Verna Benner CARSON, Handbook of Religion and Health, 2. vyd., New York: Oxford University Press, 2012.

27 Podle David R. HODGE, Spirituality and People With Mental Illness: Developing Spiritual Competency in Assessment and Intervention, Families in Society 1/2004, s. 36; Jaro KŘIVOHLAVÝ, Psychologie zdraví, 3. vyd., Praha: Portál, 2009, s. 157-162; Marc GALANTER et al., Assessment of spirituality and its relevance to addiction treatment, Journal of Substance Abuse Treatment 3/2007, s. 257-264. 
with Annotations) od Edwarda Candy a kolegů z roku $1999^{29}$ registrovalo celkem 550 publikací, druhé vydání o 4 roky později již 770 publikací, což znamená nárůst o $40 \%{ }^{30} \mathrm{~V}$ roce 2000 sestavil Hodge následující seznam poznatků o vlivech religiozity a spirituality relevantních pro sociální práci: ${ }^{31}$

Pozitivní asociace s

- úspěšným stárnutím;

- spokojeným manželstvím;

- meziosobním přátelstvím;

- odolností;

- zvládáním;

- vưdčí rolí uvnitř minority;

- porozvodovou stabilizací.

Snížená míra

- zneužívání návykových látek;

- úmrtnosti;

- nemocnosti;

- bezdomovectví;

- sexuálního násilí.

Nárůst zájmu však není všude stejný. Jak ukázaly dva srovnávací výzkumy sociálních pracovníků $(1997,2008)$ v USA, Británii, Norsku a na Novém Zélandě, je britská nebo např. norská komunita sociálních pracovníků ohledně možností práce se spiritualitou/religiozitou klientů ve srovnání s komunitou v USA výrazněji opatrnější až skeptičtější. ${ }^{32}$

\section{Jak?}

\section{Procesuální model spirituální citlivosti charitních služeb}

Diskurz spirituality navrhuji kultivovat v prostředí charitních služeb tak, aby obsahoval pět dílčích konceptů, které je vhodné zakomponovat do kompetenční výbavy jednotlivých pracovníků přímé praxe s klienty $\mathrm{v}$ pořadí naznačeném na obrázku č. 1.

Autoři z oblasti zdravotnictví věnují v konceptu spirituálních potřeb pozornost převážně technické rovině kompetence ošetřovatele či lékaře. Jen výjimečně reflektují předpoklady na individuální úrovni pracovníka ${ }^{33}$ a úroveň kultury organizace zmiňují nanejvýš v podobě stížnosti na nepři-

29 Srov. Edward R. CANDA et al., Spirituality and Social Work: A Comprehensive Bibliography with Annotations, Council on Social Work Education, 1999.

30 Srov. Connie KVARFORDT - Michael SCHERIDAN, Predicting the Use of Spiritually-based Interventions with Children and Adolescents: Implication for Social Work Practice, Currents: New Scholarship in Human Services 1/2010, s. 2.

31 Srov. David R. HODGE, Spirituality: Toward a Theoretical Framework, Social Thought 4/2000, s. 3-4.

32 Srov. Edward R. CANDA - Leola Dyrud FURMAN, Spiritual Diversity in Social Work Practice. The Heart of Helping, 2. vyd., Oxford University Press, 2010, s. 370-375.

33 Daniel Sulmasy požaduje po lékaři následující kroky: začít věnovat pozornost zaprvé signálům vycházejícím přímo od pacienta, zadruhé důležitosti vztahu lékař-pacient, zatřetí spirituálnímu poučení, které i pro něj plyne z pacientovy situace, začtvrté vlastní spiritualitě a způsobu, jak ovlivňuje jeho péči o pacienty, a zapáté začít zjištovat spirituální příběh pacienta, srov. Daniel P. SULMASY, Addressing the Religious and Spiritual Needs of Dying Patients, Western Journal of Medicine 4/2001, s. 253. 
pravenost nemocničního prostředí. ${ }^{34}$ Oproti tomu autoři ze sociální práce kladou na organizační faktory spirituálně citlivé praxe značný důraz. ${ }^{35} \mathrm{~V}$ rámci tohoto rozlišení individuální a organizační úrovně spirituálně citlivé charitní praxe zohledňuje zde prezentovaný model pouze onu individuální úroveň profesionální kompetence.

Obrázek č. 1. Schéma procesuálního modelu implementace spirituality v charitních službách
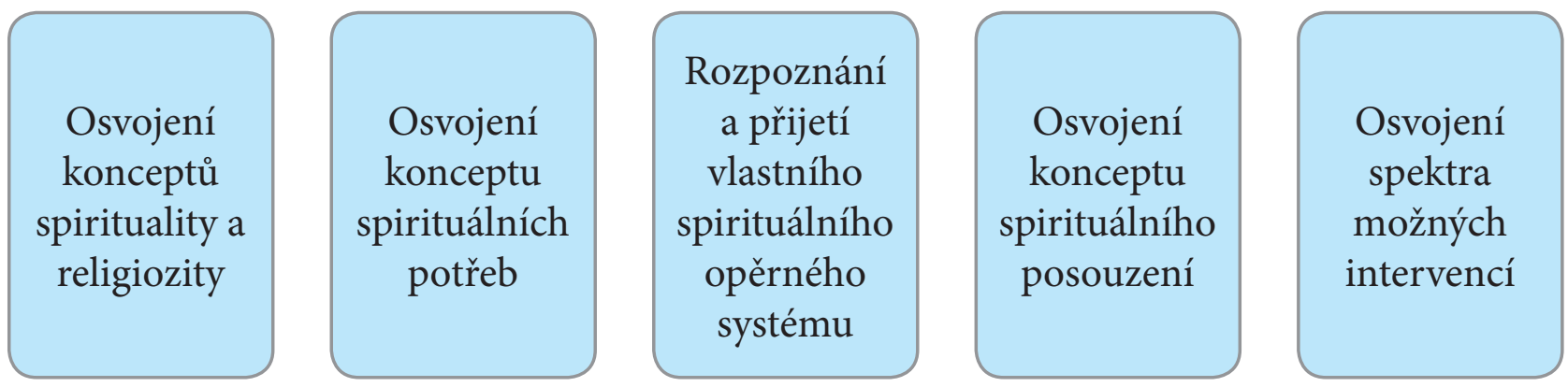

Autoři většinou zahajují seznámení čtenáře s jednotlivými součástmi spirituálně citlivé praxe osvětlením konceptů spirituality a náboženství (religiozity) v hlavním proudu diskurzu pomáhajících profesí, zejména sociální práce a ošetřovatelství. ${ }^{36}$ Tento krok pomůže předejít zaměňování obou pojmů, z toho plynoucí zúžení perspektivy pro posouzení klientovy životní situace a také pomůže lépe se zorientovat ve vlastním spirituálním př́běhu. Poté mohou být pracovníci obeznámeni s několika modely konceptualizace spirituálních a náboženských potřeb klientů z různých cílových skupin, jimž dané charitní zařízení nabízí služby. Širší spektrum modelů a jejich obsahů mohou u pracovníků zmenšit riziko, že jim uniknou relevantní signály a informace od klienta. Nejpozději po tomto kroku je nutné poskytnout pracovníkům vhodné podněty a prostor pro sebezkušenost zaměřenou k rozpoznání a přijetí vlastního spirituálního systému, o němž mohou mít menší či větší povědomí. Avšak stejně dobře by bylo možné tuto fázi spojit již s prvním krokem. ${ }^{37} \mathrm{~V}$ každém případě sebeorientace $\mathrm{v}$ této dimenzi vlastního života nejenže zvyšuje empatickou citlivost vůči klientovi, ale pomáhá také předcházet situacím protipřenosu nebo dokonce manipulaci s klientem. Teprve po této fázi př́pravy je možné si teoreticky i prakticky osvojovat dovednost spirituálního posouzení klientovy situace, které vede podle zvolené perspektivy k detekci nenaplněných potřeb, nebo zdrojů, o něž se klient může znovu opřít. Na základě posouzení je možné navrhnout, provést a vyhodnotit vhodné intervence. Zvažování a volbu charitnímu pracovníkovi usnadní přehled spektra intervencí, o nichž referuje odborná literatura.

\section{Osvojení konceptů spirituality a religiozity}

Nezbytným předpokladem pro zvážení možností práce se spirituální dimenzí klientovy situace je porozumění základním pojmům a konceptům. V oblasti diskurzu pomáhajících profesí, jako jsou

34 „Spirituální potřeba nemocných bývá často potlačena v anonymním prostředí nemocnic [...] V nemocnicích i v dnešní době chybí akceptace duchovního rozměru péče", Erika HAJNOVÁ FUKASOVÁ - Radka BUŽGOVÁ - David FELTL, Hodnocení duchovních potřeb, s. 18 .

35 James R. DUDLEY, Spirituality Matters in Social Work: Connecting Spirituality, Religion, and Practice. New York: Routledge, 2016, s. 105107, 167-168, 242-247. Canda a Furmanová shrnují reflexi tohoto organizačního zázemí do kapitoly „Vytvářet spirituálně senzitivní context praxe“, srov. Edward R. CANDA - Leola Dyrud FURMAN, Spiritual Diversity, s. 213-242.

36 „Spirituálně citlivá praxe přirozeně začíná pochopením konceptů spirituality a náboženství, James R. DUDLEY, Spirituality Matters, xvi.

37 Jak postupovali např́ílad Edward R. CANDA - Leola Dyrud FURMAN, Spiritual Diversity, s. 59-97. 
ošetřovatelství a sociální práce, se v posledních dvou dekádách ustálilo přesvědčení o užitečnosti odlišovat pojmy spiritualita a religiozita. ${ }^{38}$ Ačkoliv se autoři neshodnou na jednotné definici, rozdíly v definování obou konceptů nejsou dramatické. Vhodné poučení čtenář nalezne u Kaňáka. ${ }^{39}$ Př́kladem odlišování obou konceptů může být renomovaná publikace ze sociální práce Spirituální různorodost v sociální práci:

Spiritualita označuje na univerzální kvalitu lidí a jejich kultur a souvisí s hledáním smyslu, účelu, morality, transcendence, blaha a hlubokých vztahů k sobě, druhým a konečné realitě, jakkoliv je tato [konečná realita] chápaná. ${ }^{40}$

Náboženství představuje institucionalizovanou soustavu hodnot, přesvědčení, symbolů, chování a zkušeností orientovaných k duchovním záležitostem, sdílenou komunitou a předávanou v čase. ${ }^{41}$

Obdobné vymezení nalezneme i u dalších autorů sociální práce ${ }^{42}$ nebo lékařství. ${ }^{43}$ Autoři jsou většinou zajedno v tom, že religiozitu chápou jako dílčí součást spirituality, kterou lidé většinou projevují religiózně, nábožensky, mnozí ji ale vyjadřují raději svým vztahem k přírodě, hudbě, umění, sportu, určitému filosofickému směru nebo k přátelům a rodině, tedy nenábožensky a sekulárně. ${ }^{44}$

Fáze rozlišení konceptů spirituality a religiozity pomůže předcházet situacím konceptuální záměny obou pojmů, kdy se $\mathrm{z}$ klientovy náboženské/církevní př́íslušnosti, pokud vůbec aktivně zjištované, vyvozují informace o klientových spirituálních preferencích, přáních, potřebách a zdrojích.

\section{Osvojení konceptu spirituálních potřeb}

Charitní pracovníky je třeba seznamovat s modely duchovních potřeb, jak byly rozlišeny na základě empirických výzkumů u různých cílových skupin pomáhajících profesí. Příklady jsou uvedeny v tabulkách 1-4. Jejich společným znakem je, že působivě ilustrují šíři toho, co pacienti a klienti sami považují za spirituální potřeby ve srovnání s tradičními indikátory, jako je přijímání svátostí či návštěva nemocničního kaplana. Pochopitelně nejde o suché memorování publikovaných schémat. Vyšší kompetenci pracovník získá, pokud se seznámí s charakteristikami jednotlivých dílčích potřeb, ilustracemi situací a výroků, na jejichž základě byly zaznamenány, a propojuje tyto poznatky s vlastní zkušeností kontaktů s klienty.

Důležitou zásadou pedagogiky spirituálních potřeb je vědomí, že u konkrétního pacienta je třeba očekávat individuální konstelaci potřeb. Ne každý pacient tedy pocituje všechny potřeby. Obezná-

38 Referenčním bodem tohoto textu tedy není spiritualita $\mathrm{z}$ hlediska křestanské tradice a spirituální teologie. Kř̌estanská a katolická kultivace spirituality pomáhajícího či př́ijemce pomoci představuje „druhý krok“, který není předmětem tohoto př́spěvku.

39 Jan KAŇÁK, Postavení diskurzu spirituality, s. 32-34.

40 Edward R. CANDA - Leola Dyrud FURMAN, Spiritual Diversity, s. 59.

41 Tamtéž.

42 Religiozita: „Sdílená soustava víry a praxe, vytvořená a institucionalizovaná v komunitním prostředí, David R. HODGE - Violet E. HORVATH, Spiritual Needs in Health Care Settings: A Qualitative Meta-Synthesis of Clients' Perspectives, Social Work 4/2011, s. 308. Spiritualita: „Hledání účelu a smyslu v životě, vědomí spojení se sebou, druhými, a s univerzem, a schopnost překročit naši bezprostřední zkušenost směrem k něčemu většímu, co mnozí označují jako ,vyšší moc` za hranicemi té lidské“, James R. DUDLEY, Spirituality Matters, s. 6.

43 „Spiritualita je osobní hledání porozumění nejhlubším otázkám o životě, významu a vztahu k posvátnu či transcendenci, což může (anebo nemusí) vézt k náboženským rituálům a komunitní formaci, nebo z nich vycházet", Harald G. KOENIG - Michael E. MCCULLOGH - David B. LARSON, Handbook, s. 18. „Náboženství je organizovaný systém přesvědčení, praxe, rituálů a symbolů určených $\mathrm{k}$ (a) usnadnění blízkosti vůči posvátnu či transcendenci (Bůh, vyšší moc, nejvyšší pravda/realita) a $\mathrm{k}$ (b) podpoře vědomí vztahu a odpovědnosti jednotlivce vůči druhým v komunitě", tamtéž.

44 Srov. Daniel P. SULMASY, A Biopsychosocial-Spiritual Model for the Care of Patients at the End of Life, The Gerontologist 3/2002, s. 25. 
mení s širším spektrem publikovaných modelů tak slouží především k vytvoření představivosti a citlivosti k individuální situaci klienta. ${ }^{45}$

Tab. 1. Spirituální potřeby jihočeských seniorư ${ }^{46}$

Vědomí vlastní důstojnosti a hodnoty

Smyslu a kontinuity životního př́iběhu

Víry a důvěry

Naděje a cíle

Lásky

Tab. 2. Duchovní potřeby psychiatrických pacientữ ${ }^{47}$

\begin{tabular}{|l|l|}
\hline $90 \%$ & Péče a podpora od druhých \\
\hline $84 \%$ & Vědět o Boží prítomnosti \\
\hline $80 \%$ & Modlitba \\
\hline $75 \%$ & Smysl a význam života \\
\hline $65 \%$ & Návštěva kaplana a modlitba s ním \\
\hline $59 \%$ & Návštěva duchovního \\
\hline $51 \%$ & Pomoc od strachu ze smrti \\
\hline $39 \%$ & Svátosti \\
\hline
\end{tabular}

Tab. 3. Spirituální potřeby ve zdravotnickém prostředi ${ }^{48}$

Smysl, význam a naděje

Vztah k Bohu

Duchovní praxe

Náboženské závazky

Meziosobní vazby

Komunikace s odborným personálem

Tab. 4. Spirituální potřeby neuroonkologických pacientư ${ }^{49}$

Rodinná podpora

Emocionální podpora

Potřeba být ve spojení / opuštěnost

45 Srov. David R. HODGE - Violet E. HORVATH, Spiritual Needs, s. 312.

46 Podle Věra SUCHOMELOVÁ, Senioři a spiritualita, s. 217.

47 Georg FITCHETT et al., The Religious Needs and Resources of Psychiatric Inpatients, The Journal of Nervous and Mental Disease 5/1997, s. 320-326.

48 David R. HODGE - Violet E. HORVATH, Spiritual Needs, s. 306-316.

49 Podle Aline NIXON - Aru NARAYANASAMY, The spiritual needs, s. 2259-2270. 


Náboženské potřeby
Povídat si
Útěcha
Samota
Plánovat budoucnost / cítit se normálně
Přemýšlet o smyslu života

Značnou oporu pro charitní pracovníky s ošetřovatelským vzděláním a ve zdravotnickém prostř̌edí charitních služeb může na základě své odborné legitimity představovat koncept spirituální tísně/strádání (distres). V klasifikaci ošetřovatelských diagnóz NANDA (North American Nursing Diagnosis Association) byl poprvé zařazen již v roce $1980,{ }^{50}$ resp. $1978 .{ }^{51} \mathrm{~V}$ nejnovějším vydání je spirituální strádání definováno jako „stav strádání zpo̊sobený narušenou schopností prožívat smysluplný život prostřednictvím spojení se sebou samým, druhými, světem nebo nadřazenou bytostí'. 52 Jiná definice uvádí „stav, v němž je pacientův systém přesvědčení nebo hodnot, jež mu poskytují energii, naději a smysl do života, ohrožen poruchou“. ${ }^{53}$ NANDA manuál připojuje charakteristiku určujících znaků diagnózy a seznam souvisejících faktorů. Navíc je třeba upozornit, že NANDA poskytuje ošetřovatelskému personálu ještě širší rámec pro uchopení spirituální dimenze pacientovy situace. Desátá doména, nazvaná „životní principy“, kam autoři spirituální strádání zařazují, obsahuje charakteristiky jedenácti dalších relevantních diagnóz. ${ }^{54}$

\section{Rozpoznání a přijetí vlastního spirituálního opěrného systému}

Autoři z prostředí ošetřovatelství i sociální práce upozorňují, že dříve, než se pracovník začne věnovat spirituálním potřebám či posouzení druhých, musí získat cit pro vlastní spirituální systém a orientaci v něm, ${ }^{55}$ nebot „porozumění naší vlastní spiritualitě nás př́ipraví na to, abychom byli schopni pomoci našim klientům objevit, pochopit a přijmout jejich vlastní spiritualitu“ ${ }^{56}$ Navíc se díky tomu lze vyhnout rizikům, která by narušila vztah důvěry s klientem: povrchnost, dojem plnění pouhé povinnosti, spirituální protipřenos, proselytismus, odsuzování a předsudky. ${ }^{57}$ Podobně i Svatošová varuje, že kdo „si neuvědomuje vlastní duchovní potřeby, nechce se jimi zabývat a vytěsňuje je", ten nebude schopen tento postoj diagnostikovat u klientů. Jakmile to klient zaregistruje, „stáhne se a drží si ho od těla. Změní téma rozhovoru, mlčí nebo dá nějak jinak najevo

50 Srov. Erika de CASSIA LOPES CHACES et al., Efficacy of different instruments for the identification of the nursing diagnosis spiritual distress, Revista Latino-Americana de Enfermagem 4/2011, s. 903.

51 Srov. Heather HERDMANN - Shigemi KAMITSURU (eds.), NANDA International: Ošetřovatelské diagnózy. Definice \& klasifikace 2015-2017, 10. vyd., Praha: Grada, 2015, s. 340.

52 Heather HERDMANN - Shigemi KAMITSURU (eds.), NANDA International, tamtéž.

53 Stefanie MONOD et al., The spiritual distress assessment tool: an instrument to assess spiritual distress in hospitalised elderly persons, BMC Geriatrics 10:88/2010, s. 1 .

54 Snaha zlepšit duchovní well-being (pohodu); snaha zlepšit rozhodování; konflikt při rozhodování; zhoršení svobodného rozhodování; snaha zlepšit svobodné rozhodování; morální strádání; zhoršená religiozita; snaha zlepšit religiozitu; riziko zhoršené religiozity; riziko duchovního strádání, srov. Heather HERDMANN - Shigemi KAMITSURU (eds.), NANDA International, s. 329-342.

55 Srov. James R. DUDLEY, Spirituality Matters, s. 25-49; Miriam GEORGE - Vanessa ELLISON, Incorporating Spirituality into Social Work with Migrants, British Journal of Social Work 6/2015, s. 1721-1722; Ian GOVIER, Spiritual care in nursing: a systematic approach, Nursing Standard 17/2000, s. 35.

56 James R. DUDLEY, Spirituality Matters, s. 26.

57 Srov. David R. HODGE - Robin P. BONIFACE - Rita Jing-Ann CHOU, Spirituality and Older Adults: Ethical Guidelines to Enhance Service Provision, Advances in Social Work 1/2010, s. 5-6. 
svůj nezájem pokračovat v rozhovoru [...] “. ${ }^{58} \mathrm{Na}$ cestě k této kompetenci, kterou autoři v sociální práci někdy nazývají „spirituální kompetence ${ }^{\text {“59, }}$, lze použít řadu praktických nástrojů spirituálního sebeposouzení. V literatuře je $\mathrm{k}$ tomuto účelu $\mathrm{k}$ dispozici množství méně či více formálních nástrojů. Pro ilustraci uvedu soubor otázek podle Goviera: ${ }^{60}$

- V co věrím?

- Co dává mému životu smysl?

- V co doufám?

- Koho mám rád a kdo má rád mě?

- Co si predstavuji pod pojmem spiritualita?

- Jak jsem na tom ve vztahu $k$ druhým?

- Co bych na svých vztazích zmènil?

- Jsem ochoten uzdravit ty vztahy, které mě tíží?

Další otázky vhodné k sebereflexi pracovníka navrhuje Anemone Eglin ze švýcarského Institut Neumünster. Čtenář je může nalézt v letním dvojčísle časopisu Sociální služby z roku $2016 .{ }^{61}$ Jinou pomůckou pro spirituální sebehodnocení mohou být položky „Sebehodnotící škály spirituality“ (Spirituality Self-Rating Scale) od Galantera a kol., kterou sice vytvořili primárně pro oblast léčby závislostí, ale šest z uváděných tvrzení situaci závislosti explicitně nezmiňuje. V klinickém využití klient vyjadřuje míru svého souhlasu v rozpětí 1 (naprosto souhlasím) až 5 (naprosto nesouhlasím): ${ }^{2}$

1. Je pro mě důležité věnovat čas osobnímu duchovnímu zamyšlení a meditaci.

2. Usilovně se snažím vést život v souladu se svým duchovním přesvědčením.

3. Modlitby nebo duchovní zamyšlení o samotě jsou pro mě stejně důležité jako modlitby či zamyšlení ve společenství.

4. Rád si čtu o své spiritualitě či náboženství.

5. Spiritualita mi pomáhá udržovat životní rovnováhu a pevnost stejně jako mé občanství, přátelství a jiné vztahy.

6. Celý můj př́stup k životu se opírá o mou spiritualitu.

M. Svatošová formuluje zadání k sebeposouzení nikoliv ve formě otázek, ale čtyř úkolů: ${ }^{63}$

- připustit si svou touhu po lásce: touhu milovat a být milován;

- pokusit se o vlastní životní bilanci optikou podobenství o posledním soudu;

- přijmout svůj život včetně daností, včetně omezení a vlastní smrtelnosti;

- přijmout svůj život včetně „životního smetiště“.

\section{Osvojení konceptu spirituálního posouzení: Jak detekovat spirituální potřeby a zdroje?}

Pravděpodobně první nástroje k detekci spirituálních potřeb vznikaly v souvislosti s ošetřovatelským konceptem duchovní tísně. Již v roce 1982 představila O’Brien schéma sedmi komponent

58 Obě citace Marie SVATOŠOVÁ, Víme si rady, s. 40.

59 David R. HODGE, Spirituality and People With Mental Illness: Developing Spiritual Competency in Assessment and Intervention. Families in Society 1/2004, s. 39-40.

60 Ian GOVIER, Spiritual care, s. 35.

61 Srov. Anemone EGLIN, Spiritualita v institucích dlouhodobé péče, Sociální služby 6-7/2016, s. 38.

62 Marc GALANTER et al., Assessment of Spirituality, s. 263.

63 Srov. Marie SVATOŠOVÁ, Víme si rady, s. 40-48. 
duchovní tísně, ${ }^{64}$ jejich projevů a zjištovacích otázek kladených pacientovi. ${ }^{65}$ Jeden z nejnovějších nástrojů tohoto druhu byl publikován týmem švýcarských lékařů a staví na souboru duchovních potřeb identifikovaných u geriatrických pacientů. ${ }^{66} \mathrm{~V}$ literatuře zahraniční i tuzemské je k dispozici celá řada kvantitativních strukturovaných nástrojů pro detekci duchovních potřeb pacientů, ze zahraničních uved’me např́klad 29položkové „Šetření duchovních potřeb“ (Spiritual Needs Survey), ${ }^{67}$ 17položkový „Inventář duchovních potřeb“ (Spiritual Needs Inventory) pro pacienty paliativní péče, ${ }^{68}$ 20položkový „Index duchovního sebeposouzení pro pozdní dospělost“ (Spiritual Self-Assessment Index for Older Adults) ${ }^{69}$ nebo 19položkový „Dotazník duchovních potřeb“ (Spiritual Needs Questionnaire - SpNQ). ${ }^{70} \mathrm{~V}$ prostředí onkologických pacientů vznikl český nástroj „Hodnocení potřeb pacientů v paliativní péči“ (Patient Needs Assessment in Palliative Care - PNAP), který obsahuje také šest položek domény duchovní potřeby. ${ }^{71}$

Zdravotnická komunita ovšem evidentně vnímá limity používání podobných dotazníkových nástrojů, spočívajících v tendenci objektivizovat to, co je ve své podstatě vztahové, ve schopnosti zachytit jen abstraktní charakteristiky lidí a v riziku necitlivosti k pacientově osobní sféře života. ${ }^{72}$ Proto příslušní autoři doporučují také zařazení vhodně volených otevřených otázek. V české literatuře je již dlouho $\mathrm{k}$ dispozici sada otázek autorů z paliativního prostředí: ${ }^{73}$

- Změnila tato nemoc nějak vaše priority - např. místa, věci a životní otázky, které jsou pro vás důležité?

- Ovlivnila nemoc vaše rodinné i jiné vztahy?

- Zmènila nemoc váš pohled na vás samého?

- Zmènila nemoc váš pohled na život?

- Pokud ano, které priority jsou pro vás nejvýznamnější?

- Jaké je vaše největši próní nebo touha v této fázi života?

Nedůvěra vůči př́liš normativnímu charakteru dotazníkových nástrojů sbližuje sféru zdravotnictví se sférou sociální práce, kde je téma detekce duchovních potřeb standardně pojednáváno jako spirituální posouzení (spiritual assessment) a kde se navíc od 90. let minulého století prosazuje hledisko práce se zdroji a kapacitami klientů. Tato nová perspektiva ideálně rezonuje také s diskurzem charitní praxe, kde autoři hájí principiální orientaci na zdroje a kompetence klientů:

Diakonie vychází z toho, že všichni problémem dotčení lidé mají alespoň v zásadě vlastní kompetence k jejich zvládání, nebot’ nahlíží na každého člověka jako bytost vybavenou pozitivními životními zdroji. Přitom však neignoruje, že takové zdroje a z nich plynoucí kompetence mohou být $\mathrm{z}$ mnoha důvodů značně omezeny. ${ }^{74}$

64 Duchovní bolest, odcizení, úzkost, vina, ztráta, hněv a beznaděj. Srov. Mary Elisabeth O’BRIEN, The Need for Spiritual Integrity, in: Human Needs 2 and the Nursing Process, eds. Helen YURA - Mary B. WALSH, Norwalk, CT: AppletonCentury7C-rofts, 1982, s. 106107.

65 Např. u duchovní bolesti: „Cítíte někdy bolest s ohledem na svou spiritualitu nebo víru? Cítíte bolest z nejistoty nebo slabé víry?“, tamtéž.

66 Srov. Stefanie MONOD et al., The spiritual distress, s. 1-9.

67 Srov. Kathleen GALEK et al., Assessing a Patient's Spiritual Needs, Holistic Nursing Practice March/April 2005, s. 62-69.

68 Srov. Carla HERMANN, Development and Testing of the Spiritual Needs Inventory for Patients Near the End of Life, Oncology Nursing Forum 4/2006, s. 737-744.

69 Srov. Suzanne STRANAHAN, Spiritual self-assessment index for older adults, Journal of Religion \& Health 47/2008, s. 491-503.

70 Srov. Arndt BÜSSING et al., Spiritual needs of patients with chronic pain diseases and cancer - validation of the Spiritual Needs Questionnaire, European Journal of Medical Research 6/2010, s. 266-273.

71 Srov. Radka BUŽGOVÁ - Renáta ZELENÍKOVÁ, Vytvoření měřícího nástroje, s. 404-414

72 Srov. Margaret O'CONNOR - Sanchia ARANDA (eds.), Paliativní péče, s. 70.

73 Tamtéž, s. 71.

74 Heinrich POMPEY - Paul-Stefan ROSS, Kirche für andere, s. 188. 
Teorie, o kterou se koncept spirituálního posouzení v sociální práci opírá, tvrdí, že úkolem sociálního pracovníka je rozklíčovat klientův systém orientace v životě, tedy to, co klient používá, aby životu rozuměl a orientoval se $\mathrm{v}$ něm. Každý druh spirituality a religiozity představuje takový orientační systém. ${ }^{75} \mathrm{~V}$ situacích stresu a těžkých životních problémů získává klientův orientační systém na významu. ${ }^{76}$ Spiritualita (je-li zdravá) se tedy může stát důležitou součástí zdrojů, o které se klient může, ba musí (ve smyslu subsidiarity) opř́t. Často však dochází k tomu, že klienta jeho problémy zavalí natolik, že své zdroje přehlíží a nedoceňuje. ${ }^{77}$ Pro sociálního pracovníka je proto důležité, aby $\mathrm{k}$ orientačnímu systému klienta získal př́stup a pomohl klientovi se o něj znovu opřít. Aby toho dosáhl, musí sociální pracovník s klientem provést spirituální posouzení. Autoři rozlišují několik typu spirituálního posouzení, avšak nejsou zajedno v jejich pojmenování. Běžně se uvádějídvě dvojice: úvodní (krátké) - podrobné a implicitní-explicitní. Účelem úvodního posouzení je zjistit, do jaké míry je spirituální systém pro klienta nosný. Na základě informací získaných z tohoto posouzení se ukáže, jaký efekt by klientova spiritualita mohla mít na poskytování služby, tedy zda jeho zastávaná spirituální přesvědčení mohou zafungovat jako bariéra či jako výhoda, ${ }^{78}$ a zda bude vhodné navázat podrobnějším rozhovorem, protože klient signalizuje, že spiritualita pro něj hraje důležitou roli, nebo naopak bude lepší klienta dále nezatěžovat, protože pro něj nemá velkou relevanci. ${ }^{79}$

Za určitý předstupeň posouzení lze považovat situaci prvního kontaktu s klientem, kdy se jeho spirituální zájmy projevují at verbálně či neverbálně a již zde je vhodné přiměřeně reagovat. Dudley pro ilustraci uvádí dva scénáře. V prvním vyzývá čtenáře $\mathrm{k}$ zamyšlení: ${ }^{80}$

Klientka: „Bez modlitby bych ty dny, jak jdou, nezvládla. Je to pro mě strašně dưležité.

Máte dovoleno se se mnou pomodlit během naší schưzky?"

Otázka: Jak byste se při takové otázce cítili? Co byste řekli, abyste klientku

povzbudili, aby vám sdělila, včem je pro ni její modlitba významná a důležitá?

Ve druhé ilustraci uvádí i možnou vhodnou reakci pracovníka: ${ }^{81}$

Bezdomovec, muž, nese viditelně svou Bibli na první setkání s přijímajícím pracovníkem.

Pracovník: „Vidím, že Bible je pro vás asi hodně di̊ležitá, že?"

Klient: „Jasně, mám ji pořád u sebe."

Pracovník: „A řeknete mi, jak vám to pomáhá? Opravdu by mě to zajímalo“"

Klient: „Když mám problémy, tak si v ní čtu určité verše."

Pracovník: „Neváhejte mi říct o těchto biblických verších, kdykoliv budete mít dojem, že by nám to mohlo pomoci najít vám bydlení."

Pro účely krátkého/úvodního posouzení lze uvést jako vhodný př́íklad schéma čtyř otázek vytvořených na základě striktního požadavku JCAHO, ${ }^{82}$ největší a nejvlivnější akreditační agentury

75 Srov. David R. HODGE, Spiritual Life Maps: A Client-Centered Pictorial Instrument for Spiritual Assessment, Planning, and Intervention, Social Work 1/2005, s. 77-87.

76 Srov. Kenneth I. PARGAMENT, The Psychology of Religion and Coping, NY: Guilford Press, 1997.

77 Srov. Denis SALEEBEY, The Strengths Perspective in Social Work Practice, 6. vyd., Boston: Pearson, 2012.

78 Klienti s určitým spirituálním přesvědčením mohou např́ílad cítit zábrany k účasti na některých typech skupinové terapie, muslimové mohou odmítat vyšetření lékařem opačného pohlaví, a naopak klientům se schizofrenií může usnadnit cestu úzdravy aktivní účast na životě církevní komunity, srov. David R. HODGE, A Template for Spiritual Assessment: A Review of the JCAHO Requirements and Guidelines for Implementation, Social Work 4/2006, s. 319-320.

79 Srov. Edward R. CANDA - Leola Dyrud FURMAN, Spiritual Diversity, s. 263; David R. HODGE, A Template, s. 319.

80 James R. DUDLEY, Spirituality Matters, s. 155.

81 Tamtéž, s. 157.

82 Joint Commission on Accreditation of Healthcare Organizations. 
zdravotnických zařízení v USA, která roku 2001 stanovila jako podmínku akreditace zařízení (nemocnice) provedení spirituálního posouzení pacientů: ${ }^{83}$

1. Je pro vás spiritualita či náboženství nějak dưležité?

2. Považujete určité duchovní názory a praktiky za obzvláště užitečné pro zvládání problémů?

3. Chodíte do nějakého kostela nebo do jiného duchovního společenství?

4. Cítíte nějaké duchovní potřeby, se kterými bych Vám mohl pomoci?

K typu krátkého, avšak explicitního posouzení je řazena sada otázek, kterou její autoři nazývají MIMBRA. ${ }^{84}$ Stejně jako u předchozího modelu je jeho výhodou, že nevytváří tlak, je určen pro situace omezeného času práce $s$ klientem, kdy je potřeba rychle zjistit, zda je spiritualita důležitá a relevantní pro jeho situaci, a poté se rozhodnout, zda se bude pracovník s klientem tímto zdrojem zabývat prrímo, nebo jej předá jinému pracovníkovi: ${ }^{85}$

Zajímalo by mě, co považujete ve svém životě za nejvýznamnější a nejdůležitější, protože by to mohlo být relevantní pro naši společnou práci. Rozhodněte se svobodnè, zda na následující otázky odpovíte, či nikoliv, a pokud odpovite, odpovídejte tak, aby vám to dávalo smysl.

1. Co vám pomáhá, abyste hlouběji vnímal ve svém životě smysl, moralitu, naději, propojení, radost či pokoj?

2. Jsou pro vás spiritualita, náboženství a víra dưležité? Vysvětlete mi prosím jak, príp. proč ne.

3. Patřite do nějaké skupiny, společenství nebo komunity, v níž máte pocit, že tam náležite a že vám pomáhá nalézat v životě smysl a oporu? Prosím vysvětlete.

4. Popište mi prosím jakákoliv důležitá přesvědčení, zvyky a praktiky (modlitba, meditace, rituály nebo holistické terapie) nebo hodnoty, které vám pomáhají rozumět vaší momentální situaci.

5. Co z toho, o čem jste mluvil, je relevantní pro vaší momentální situaci a vaše cíle naší společné práce?

6. Je v tom, o čem jste hovořil, něco, na čem bychom měli společně pracovat? Např̀. je něco, co vám dřive pomáhalo a my bychom to mohli použít, nebo je něco nepř́iemného, čemu bychom se měli vyhnout? Máte nějaké prrátele, př́buzné, rádce, duchovní nebo jiné duchovní autority, o kterých bych měl vědět nebo je kontaktovat? Prosím vysvětlete. Díky.

Pokud reakce klienta na tyto otázky indikují př́itomnost spirituální perspektivy jeho situace, může pracovník postoupit k podrobnému posouzení. To může užívat bud’ spirituálně implicitní, nebo explicitní jazyk. Zejména v silně sekularizovaném prostředí může být vhodné použít implicitní spirituální posouzení, které je nejméně invazivní a používá otevřené otázky s duchovní tématikou s použitím všedního nenáboženského jazyka. Otázky lze libovolně přizpůsobovat slovníku klienta a jejich počet a pořadí není směrodatné. Canda a Furman zformulovali jako inspiraci pro sociální pracovníky dvaadvacet takových otázek, například: ${ }^{86}$

- Co dává momentálně vašemu životu smysl?

- Co vám pomáhá soustředit se a cítit se bdělý?

- Kam chodíte načerpat vnitřní inspiraci a klid?

- V jakých chvílích cítíte vnitřní pokoj a životní spokojenost?

- Z čeho čerpáte, abyste překonal obtíže a krize?

83 David R. HODGE, A Template, s. 319.

84 Podle: Meaning, Importance, Membership, Beliefs, Relevance, Action.

85 Edward R. CANDA - Leola Dyrud FURMAN, Spiritual Diversity, s. 267.

86 Tamtéž, s. 266. 
- Prosím popište mi, kdy jste naposled zažil nějaký di̊ležitý vhled, nějaký důležitý „aha“ okamžik.

- U koho hledáte radu a proč?

- Za co jste nejvíce vděčný?

- Čím je pro vás dìležité být na světě (v této situaci)?

- Co jsou vaše nejcennější ideály?

- Co pokládáte za nejdůležitější v životě?

D. Hodge zorganizoval otázky k implicitnímu posouzení podle časové linie klienta: spiritualita minulá, př́tomná a budoucí. Z celkové sady čtyřiceti otázek vybírám s ohledem na omezený prostor v tomto článku jen př́klady: ${ }^{87}$

Spirituální minulost

- Když se díváte nazpět, odkud jste bral/a pocit smyslu (nebo naděje pro budoucnost)?

- Kdy jste byl nejvíce štastný?

- Jak jste v minulosti zvládal obtížné situace?

Současná spiritualita

- Kdy nejvíc cítíte, že žijete?

- Co vám působí největší beznaděj/utrpení?

- Co v životě ve vás vyvolá nejvíce vášnivosti?

- Do koho nebo čeho vkládáte svou naději?

- Za co jste nejvíce vděčný/á?

- Čeho nejvíce litujete?

- Kde nacházíte pramen vnitřního klidu (inspirace)?

- Odkud čerpáte, abyste se pohnul z místa, když je to v životě těžké?

- Čemu nebo komu jste nevíce oddaný?

- Kdo vám rozumí nejvíc?

Budoucí spiritualita

- O co v životě usilujete?

- Proč je pro vás dưležité být na tomto světě?

- Jak byste chtěl, aby na vás lidé vzpomínali, až odejdete?

Pro účely detailního a explicitního posouzení nabízejí autoři pestrou paletu nástrojů, které pomáhají strukturovat rozhovor, ${ }^{88}$ nebo využívají prvky vizualizace. Hodge vyvinul a publikoval celkem pět takových nástrojů: ${ }^{89}$

- duchovní historie - slovní popis klientova duchovního př́iběhu;

- duchovní mapa života - zahrnuje totéž, ale používá obrazový formát a je tudíž vhodná spíše pro umělecky zručné a málomluvné klienty;

- duchovní genogram - mapuje vývoj spirituality minimálně napříč třemi generacemi a je vhodný tam, kde v klientově situaci hraje důležitou roli širší rodina;

- duchovní ekomapa - znázorňuje klientovu přítomnost, existenciální vazby klienta na klíčové duchovní proměnné v jeho prostředí a je tudíž vhodnější pro klienty, pro něž není ohlížení do

87 David R. HODGE, Implicit Spiritual Assessment: An Alternative Approach for Assessing Client Spirituality, Social Work 3/2013, s. 227

88 Srov. Edward R. CANDA - Leola Dyrud FURMAN, Spiritual Diversity, s. 379-383.

89 Srov. David R. HODGE, Spiritual Life Maps:, s. 77-87. David R. HODGE, Spiritual Ecograms: A New Assessment Instrument for Identifying Clients' Spiritual Strengths in Space and Across Time, Families in Society 2/2005, s. 287-296; David R. HODGE, Spiritual Assessment in Marital and Family Therapy: A Methodological Framework for Selecting from among Six Qualitative Assessment Tools, Journal of Marital and Family Therapy 4/2005, s. 341-356; David R. HODGE, Developing a Spiritual Assessment Toolbox: A Discussion of the Strengths and Limitations of Five Different Assessment Methods, Health \& Social Work 4/2005, s. 314-323. 
minulosti zajímavé;

- duchovní ekogram - slučuje výhody tradičního genogramu a ekomapy a umožňuje sociálnímu pracovníkovi prozkoumat vztahy mezi prŕítomnými a minulými vlivy.

\section{Pravidla a předpoklady pro spirituální posouzení}

Autoři formulují celou řadu podmínek a doporučení, které je nutné zajistit pro detekci spirituálních potřeb a realizaci spirituálního posouzení. ${ }^{90}$ Vzhledem $\mathrm{k}$ formátu tohoto příspěvku se omezím na velmi stručnou informaci.

- Je nutné dbát na autonomii klienta. V profesionálním mandátu není možné ani v prostředí charitních služeb klientovi vnucovat spirituální představy někoho jiného. Součástí mandátu však může být nabídka reflektovat s klientem rizika jeho spirituálního systému.

- Je nutné zůstávat v mezích vlastní kompetence. Cílem duchovního posouzení je identifikovat potřeby či zdroje, které klientovi potenciálně mohou překážet či pomáhat ve zvládání vlastní životní situace. Cílem není poskytovat klientovi duchovní vedení, které je doménou duchovních a pastoračních pracovníků.

- Duchovní potřeby jsou naplňovány vždy v kontextu vztahu. Východiskem a předpokladem je tedy navázání pomáhajícího vztahu s jeho klasickými parametry (tzv. common factors), jako je empatie, opravdovost, bezpodmínečné přijetí, vřelost atd. ${ }^{91}$ Pomáhající vztah s těmito parametry je už implicitně spirituální. ${ }^{92}$

\section{Osvojení spektra možných intervencí}

Zahraniční literatura sociální práce dnes poskytuje bohatý zdroj informací o tom, jaké postupy a intervence sociální pracovníci při práci používají, jak na úrovni přímé práce s klientem (mikro) nebo na úrovni práce s organizacemi a s komunitami (makro). ${ }^{93}$ Díky pozorné analýze Jana Kaňáka je několik desítek $\mathrm{z}$ nich dostupných také českému čtenáři a charitním pracovníkům. ${ }^{94}$ V tomto př́íspěvku je tedy nebudu více rozvíjet. Seznámení s možnostmi má za cíl oslabit eventuální předsudky o neslučitelnosti spirituálně založených (spiritually based) či spirituálně orientovaných (spiritually oriented) postupů s vlastním profesionálním mandátem a dále podnítit kreativitu a reflexi, jaké z postupů by připadaly v úvahu v individuální situaci mandátu pracovníka a životní situace klienta.

90 Srov. Vincent STARNINO - Sachiko GOMI - Edward CANDA, Spiritual Strengths Assessment in Mental Health Practice, British Journal of Social Work 4/2012, s. 858-861; David R. HODGE, A Template, s. 320-323; David R. HODGE - Robin P. BONIFACE - Rita Jing-Ann CHOU, Spirituality and Older Adults, s. 3-10; Edward R. CANDA - Leola Dyrud FURMAN, Spiritual Diversity, s. $213-222$.

91 Uznávaný výzkumník v této oblasti John C. Norcross uvádí následující soubor parametrů terapeutického vztahu: empatie, aliance/ koheze, shoda $\mathrm{v}$ cílech spolupráce, pozitivní zájem (bezpodmínečné přijetí), kongruence, zpětná vazba, náprava poruch aliance, sebeodhalení terapeuta, management protipřenosu a kvalita vztahových interpretací, srov. John NORCROSS, Therapeutic relationship, in: Barry L. DUNCAN et al. (eds.), The Heart and Soul of Change: Delivering What Works in Therapy, 2. vyd., Washington DC: APA, 2010, s. 113-141.

92 Je třeba připomenout, že podle výzkumů je účinnost psychoterapie ze 7-30 \% závislá na kvalitě pomáhajícího vztahu, srov. Edward R. CANDA - Leola Dyrud FURMAN, Spiritual Diversity, s. 214.

93 Edward R. CANDA - Leola Dyrud FURMAN, Spiritual Diversity, s. 314-361; James R. DUDLEY, Spirituality Matters, s. 205-268; David R. HODGE, Spiritual Life Maps, s. 77-87; Michael J. SHERIDAN, Predicting the Use of Spiritually-Derived Interventions in Social Work Practice: A Survey of Practitioners, Journal of Religion \& Spirituality in Social Work 4/2004, s. 5-25; Connie KVARFORDT - Michael SHERIDAN, Predicting the Use of Spiritually-Based Interventions with Children and Adolescents: Implication for Social Work Practice, Currents: New Scholarship in Human Services 1/2010, s. 13-17; David R. HODGE - Robin P. BONIFAS, Using Spiritually Modified Cognitive Behavioral Therapy to Help Clients Wrestling with Depression: A Promising Intervention for Some Older Adults, Journal of Religion \& Spirituality in Social Work: Social Thought 3/2010, s. 185-206; David R. HODGE, Spirituality and People With Mental Illness, s. 41-42.

94 Jan KAŇÁK, Nedefinovaná profesionalita, s. 81-85. 
Pro zdravotnicky zakotvené charitní pracovníky bude bezpochyby užitečnější poukázat na možnosti postupů, které odpovídají jejich kompetencím. V tomto ohledu nelze opomenout studii, kterou uskutečnili Roberta Cavendish s kolegyněmi. ${ }^{95} \mathrm{Z}$ celkových 404 zdravotních sester referovalo 18 \% (97) o používání 34 typů „aktivit duchovní péče“ o pacienty a o sebe. Výzkumnice následně přiřadily referované aktivity ke kategoriím (labels) a aktivitám popsaným $\mathrm{v}$ „Klasifikaci ošetřovatelských intervencí (Nursing Interventions Classification - NIC ${ }^{96}$ ). Z celkem deseti detekovaných kategoriíp ${ }^{97}$ uvedu pro ilustraci jen aktivity prvních dvou: ${ }^{98}$

Facilitace duchovního růstu

- podněty ke konverzaci pomáhající pacientovi utř́dit si duchovní záležitosti;

- nabizet individuální a skupinovou podporu v modlitbě, je-li to vhodné;

- podněty k účasti na liturgických akcích, modlitbách nebo studijních programech;

- podpora vztahů se souvěrci;

- podněty k účasti na duchovním slavení a rituálech;

- vytvoření prostředí podporujícího meditativní sebereflexi;

- zprostředkování kontaktu na podpuirnou skupinu, svépomocnou skupinu nebo duchovně založenýprogram;

- zprostredkování kontaktu na pastorační péči.

Duchovní opora

- podněty k návštěvě nemocniční kaple;

- podněty k využívání duchovních zdroju;

- poskytnutí vyžádaných duchovních článki̊;

- facilitace pacientova zpiosobu meditace, modlitby a jiných náboženských tradic;

- pečlivé naslouchání pacientově komunikaci a vytvoření vnímavosti vưči načasování modliteb a duchovních rituálì;

- ujištění pacienta, že sestra bude dosažitelná v době bolesti;

- být otevřen pacientovým pocitům ohledně nemoci a smrti.

\section{Závěr}

Pohled do diskurzů sociální práce a zdravotnictví, tedy dvou referenčních oborů, o něž se dnešní praxe služeb charity opírá, ukázal masivní zájem o zkoumání a integraci konceptu duchovních potřeb a souvisejících konceptů, jako duchovní strádání, duchovní zdroje, duchovní (sebe)posouzení atd. Ve smyslu teologické premisy „gratia supponit naturam“ se zdravá charitní praxe o tyto poznatky a kompetence může, ba musí v nějaké míře a podobě opřít, používat je, začít je kriticky reflektovat a výsledky zkušenosti dále publikovat. Jen tak může o charitních službách platit, analogicky k lékařství, že jsou poskytovány „lege artis“. S ohledem na duchovní potřeby a zdroje př́jemců není v charitách legitimní volit strategii tabuizace či alibistické a unáhlené delegace na duchovní, kaplany, pastorační pracovníky a jiné subjekty exkluzivních kompetencí. Praktická teologie doposud zůstávala pracovníkům v charitách dlužna, co se týče podnětů pro realizaci služeb v takové kvalitě, která integruje i spirituální dimenzi životní situace jejich adresátů. Předložený

95 Roberta CAVENDISH et al., Spiritual Care Activities of Nurses Using Nursing Interventions Classification (NIC) Labels, International Journal of Nursing Terminologies and Classifications 4/2003, s. 113-124.

96 Srov. nejnovější edici Gloria M. BULECHEK et al. (eds.), Nursing Interventions Classification (NIC), 6. vyd., St. Louis: Elsevier-Mosby, 2013.

97 Facilitace duchovního růstu, duchovní opora, přítomnost, aktivní naslouchání, humor, dotek, terapeutický dotek, zvýšení sebevnímavosti, předání, muzikoterapie.

98 Roberta CAVENDISH et al., Spiritual Care Activities, s. 119-120. 


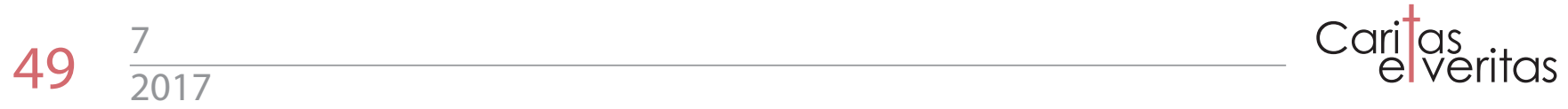

model na sebe navazujících kroků přípravy a praxe charitního personálu chce tento dluh částečně splatit. Mnohé aspekty standardně spojované s prvky předloženého modelu nebyly pojednány vưbec či jen okrajově (etická pravidla posouzení a intervencí, evaluace intervencí atd.) a vyžadují další reflexi, stejně jako hledisko organizačního zázemí, které může aplikaci spirituálně citlivé charitní praxe účinně brzdit, či naopak usnadnit.

\title{
Spirituální citlivost charitních služeb: Proč a jak pracovat se spirituální dimenzí životní situace klientư
}

\begin{abstract}
Abstrakt
V prostředí společnosti, kde tradiční církve ztratily svůj monopol na definování podmínek spirituálního života člověka, se mohou pracovníci zařízení církevních charit, ale i dalších pomáhajících organizací, cítit bezradní, jakým způsobem mají naplňovat postulát celostního přistupu k životní situaci svých klientů a pacientů, nezaměňovat koncepty spirituality a náboženství a využít rámec svých profesních kompetencí i s ohledem na spirituální dimenzi života příjemců svých služeb. Článek k tomu nabízí praktické podněty. Nejprve legitimizuje úsilí charitních pracovníků inkorporovat práci se spirituální dimenzí svých klientů za pomoci odkazu na diskurzy vedené v praktické teologii, zdravotnictví a v sociální práci. Poté představí procesuální model prípravy a praxe charitních pracovníků, zahrnující pět fází: (1.) osvojení konceptů spirituality a náboženství, (2.) osvojení konceptu spirituálních potřeb, (3.) rozpoznání a přijetí vlastního spirituálního opěrného systému, (4.) osvojení konceptu spirituálního posouzení a (5.) osvojení spektra možných spirituálně senzitivních intervencí. Jednotlivé fáze modelu jsou interpretovány a ilustrovány s pomocí odkazů do oblasti zdravotnictví a sociální práce.
\end{abstract}

Klíčová slova: spiritualita, charita, sociální práce, duchovní potřeby, spirituální posouzení, praktická teologie

\section{Kontakt na autora}

\section{ThLic. Jakub Doležel, Th.D.}

Univerzita Palackého v Olomouci

Cyrilometodějská teologická fakulta, Katedra křest’anské sociální práce

Univerzitní 244/22, 77111 Olomouc

jakub.dolezel@upol.cz 